九州大学学術情報リポジトリ

Kyushu University Institutional Repository

Taxonomic re-examination of the striped field mouse, Apodemus agrarius coreae and $A$. a. chejuensis: Evidence from crossbreeding experiments (Mammalia: Rodentia)

Oh, Hong-Shik

Zoological Lahoratory, Faculty of Agriculture, Kyushu University

Mori, Takayuki

Zoological Lahoratory, Faculty of Agriculture, Kyushu University

https://doi.org/10.5109/24261

出版情報 : 九州大学大学院農学研究院紀要. 43 (1/2)，pp.143-151，1998-11. Kyushu University バージョン：

権利関係 : 


\title{
Taxonomic re-examination of the striped field mouse, Apodemus agrarius coreae and $A$. a. chejuensis: Evidence from crossbreeding experiments (Mammalia: Rodentia)
}

\author{
Hong-Shik Oh* and Takayuki Mori** \\ Zoological Laboratory, Faculty of Agriculture, Kyushu University 46-06, \\ Fukuoká 812-8581, Japan, Fax: 092-642-2804 \\ (Rectiva June 11, 1998 and accepled August 7, 1998)
}

\begin{abstract}
In order to re-examine the taxonomic status of the striped field mouse on Cheju lsland, Korea, reproductive compatibility between local mouse populations from Cheju lsland and Pusan was cxamined in crosstreeding experimest.s. Six 1ypes of crosses, inchuling five in $A$ a chejuensis $+\times A$. a coreae $\delta$ and one in $A$. a coreae $9 \times A$. a chejuensis $\delta$, were attempted in this study. Of these, tive pairs of $A$. a chejuensis $9 \times A$. a coreaf $\AA$ crosses succeeded in producing and rearing newborl youngs. However, the forty pairs comprising their Fl gencrations had a reproduction rate as low as $5 \%$ and thus clearly had difficulty in reproduction. Moreover, we could not obtain any newborn youngs from the ten pairs of the $A$. a. coreae + + $\times A$. a. chejuensis $\delta$ crosses. The reproductive organs of $F 1$ generation from the A. a chejuensis + + $\times A$. a coreae $\delta$ cross were examined histologically. All the females were normal, while some abnormalities were observed in the males. Therefore, it was established that reproductive isolation exists between the two local populations. Conscquently, these striped field mouse populations are defined as different species
\end{abstract}

\section{INTRODUCTION}

The striped field mouse (Apodemus agrarius), widely distributing across the temperate region of the Eurasia (Corbet, 1978), belongs to Apodemus, Murinae, and includes twenty-two subspecies (Musser and Carleton, 1993). This species, in which many geographical morphometric variations are detected, is the most common among field rodents living in Korea (Hong and Lee, 1984). Thomas (1907) identified the striped field mouse from the Korean mainland and the striped field mouse from the Cheju Island as one subspecies of Micromys a. mantchuricus, but he could not find out any differences in the external morphometric characters between the populations from these two areas. Thereafter, based on morphometric characters, this species has been classified into the following two to four subspecies; two subspecies of $A$. a. pallescens and A. a. chejuensis (Johnson and Jones, 1955), two subspecies of $A$. a. manchuria and $A$. a. coreae (Kuroda, 1934; Won, 1961), and four subspecies of $A$. a. manchuria in the extreme northern part, $A$. a. coreae throughout the major portion of the peninsular, $A$. $a$. pallescens in the coastal lowlands of southern and southwestern Korea, and $A$. $a$. chejuensis on the Cheju Island (Jones and Johnson, 1965). On the other hand, in recent years, cytogenetical and biochemical analyses have been carried out on Apodemus spp. in

* Present address: Department of Science Education, College of Education, Cheju National University, Cheju, 690-756, Korea.

** To whom correspondence should be addressed, Tel: 092-642-2945. (Ext.), E-mail. tmohri @agr. kyushu-u.ac.jp 
order to make it laboratory animal, resulting in detection of a polymorphism of transferrin within those four subspecies (Tsuchiya, 1984, 1985). In addition, some taxonomists insist that the striped field mouse from the Cheju Island, is one seperate species from the results of the various analyses; i.e. the geographical variations of morphometric characters among three subspecies of the striped field mouse, $A$. a. coreae, A. a pallescens and $A$. a. cheyuensis (Koh, 1986), the morphometric and chromosomal analyses of $A$. a coreae and $A$. a chejuensis (Koh, 1987), the external and cranial characters of eight subspecies of the striped field mouse in Asia (Koh, 1991) and RFLPS variations of mitochondorial DNA in two subspecies of the striped field mouse, $A$. a. coreae and $A$. a. chejuerisis from Korea (Koh and Yoo, 1992).

Taxonomy must be grounded on integrated conclusions which were clarified by investigations from various aspects. Where the populations from the two areas is uncertainly classified based on differences in their distribution and small morphological disparities and thus it is open to dispute, more extensive studies must be done. Among many techniques, a crossbreeding experiment is one of the most effective methods to assess the differences between species level. Studies on crossbreeding experiments have been reported for Apodemus species on their inter- or intra-specific breeding results of mainland and island populations (Jewell and Fullagar, 1965), and for Clethrionomys species on their interspecic breeding results between mainland populations (Grant, 1974). Two subspccies, $A$ a coreae from the Korean mainland and $A$. a chejuensis from the Cheju Island, have been separated from each other by the ocean for a long time and have been intensely discussed about their taxonomic status compared to the remaining two subspecies. The aims of this study are to determine the reproductive compatibility and to re-examine their taxonomic status by crossbreeding experiments.

\section{MATERIALS AND METHODS}

\section{Crossbreeding experiment}

In this study, thirteen $A$. a. coreae, consisted of six males and seven females, and twenty-five $A$. a. chejuensis, consisted of thirteen males and twelve females were used as the first generation. All the striped field mice used in this study were caught in either Mt. Whangreung, Pusan in the Korean mainland or Mt. Halla, Cheju Island at different periods, on August, 1994, March and November, 1995, and August, 1996. After capturing, each mouse was bathed in Negubon solution, so that external parasites were exterminated. The breeding experiments were conducted from September, 1994 to April, 1997. All the animals were housed as breeding pairs in $24 \times 39 \times 19 \mathrm{~cm}$ cages made from polycarbonate. The cages floors were covered with wood chips and substantial straw was provided as nest materials. All the striped field mice were maintained on a $14-\mathrm{h}$ L: $10-\mathrm{h}$ D photoperiod with lights on at 08:30 hour, and the room temperature and humidity are $23{ }^{\circ} \mathrm{C}$ and $60 \%$ respectively. Water and food were available ad libitum, the diet consisting of canary seeds, Chinese foxtail and Japanese millet seeds, flax seeds, surflower seeds and a commercial diet (NMF; Oriental Yeast Co., Ltd., Tokyo). Mice used in the present experiments were as follows: A. a. chejuensis from 3 to 12 months old (weigh up to $35 \mathrm{~g}$ in fernales, $45 \mathrm{~g}$ in males); $A$. a. coreae from 3 to 12 months old (weigh up to $30 \mathrm{~g}$ in females, $40 \mathrm{~g}$ in males); hybrid F1 (A. a. chejuensis 우 $\times$. a. coreae $\vec{d}$ ) up to 3 months old 
(weigh up to $35 \mathrm{~g}$ in both sexes). To facilitate breeding, females were taken into male's cages for three months. Pregnant females were checked every day so that newborn youngs were detected within one day after birth. Breeding occurred in monthly for the year. Litter sizes were recorded at this time.

\section{Histological techniques}

The reproductive organs of F1 generation (nine males and nine females) of $A . \alpha$. chejuensis + $\times$ A. a. coreae $\delta$ were studied histologically. Each mouse was killed with diethyl ether and then the testes and cauda epididymides were removed from the inales, and the ovaries, oviducts and uteruses were removed from the females. These tissues were fixed in Bouin's solution, dehydrated in a series of ethanol followed by xylene, and embedded in Paraplast Plus (Monoject Co., Lt.d., U.S.A.). Sections were cut to a thickness of 4-5 $\mu \mathrm{m}$ and staincd with Delafield hematoxylene and eosin. The activity of spermatozoa in caudal epididymides of the males was recorded. Patterns of the development of the follicle cells and corpora lutea of the females werc observed.

\section{RESLLTS}

\section{Crossbreeding experiments}

In this study, eight types of crosses were examined, involving five types of crosses in the line of $A$. a. chejuensis 우 $\times A$. a. coreae $\delta$, one type of cross in the line of $A . a$. corece 우 $\times A$. a. chejuensis $\delta$, onc type of cross in the line of $A$. a. chejuensis 우 $\times A$. a. chejuensis $\delta$ and $A$. a. coreae $+\times \times A$. a. coreae $\gtrsim$ (Table 1). Three of the five pairs of $\Lambda$ a. chejuensis $+\times \times \Lambda$. a. coreae $\&$ (type I) succeeded in producing and rearing newborn youngs. On the other hand, the forty pairs which were composed of the first generation bred at the rate as low as $5 \%$ and, thus, a clear difficulty was detected in their reproduction. Moreover, of the three pairs which were composed of the second generation, only one pair produced and reared a litter which included five newborn youngs (reproductive rate $33.3 \%$, type III). The eight pairs of $A$. a. chejuensis o $\times$ the

Table 1. Crossbrecding results between the striped ficld mice from the Cheju island and Pusan Populations in Korea.

\begin{tabular}{|c|c|c|c|c|c|c|c|}
\hline \multicolumn{2}{|c|}{ Types of crosses } & \multirow{2}{*}{$\begin{array}{l}\text { No. of } \\
\text { pairs }\end{array}$} & \multirow{2}{*}{$\begin{array}{c}\text { Successful } \\
\text { pairs }\end{array}$} & \multirow{2}{*}{$\begin{array}{l}\text { No. of } \\
\text { litters }\end{array}$} & \multirow{2}{*}{$\begin{array}{l}\text { No. of } \\
\text { young }\end{array}$} & \multirow{2}{*}{$\begin{array}{c}\text { Mean } \\
\text { littcr size }\end{array}$} & \multirow[b]{2}{*}{ Range } \\
\hline 우 & 3 & & & & & & \\
\hline I. A. a chejuensis & $\times$ A. a. coreae & $\bar{\jmath}$ & 3 & 22 & 105 & 4.77 & $2-6$ \\
\hline II. (chejuensis $\times$ coreae) $\mathrm{F} 1$ & $\times($ chejuensis $\times$ coreae $) \mathrm{Fl}$ & 40 & 2 & 7 & 36 & 5.14 & $2-8$ \\
\hline III. (chejuensis $\times$ coreae) $\mathrm{F}^{2}$ & $\times($ chejuensis $\times$ coreae $) \mathrm{F}_{2}$ & 3 & 1 & $\ell$ & 5 & 5.0 & 5 \\
\hline V. A. a chejuensis & $\times($ cheinensis $\times$ coreas $) \mathrm{F} 1$ & 8 & 3 & 5 & 24 & 4.8 & $4-5$ \\
\hline $\mathrm{V} .($ chejuensis $\times$ coreae $) \mathrm{F} 1$ & $\times A$, a chejuensis & 10 & 2 & 3 & 17 & 5.67 & $5-6$ \\
\hline VI. A. a coreae & $\times$ A. a chejuensis & 10 & 0 & - & - & - & - \\
\hline VI. A. a. chejuensis & $\times$ A. a chejuensis & 23 & 19 & 60 & 276 & 4.6 & $2-9$ \\
\hline VII. A. a. coreae & $\times$ A. a. coreat & 11 & 8 & 23 & 109 & 4.73 & $2-7$ \\
\hline
\end{tabular}


first generation (F1) $\delta$ (type IV) and the ten pairs of the first generation (F1) 우 $\times$ A. $a$. chejuensis $\delta$ (type $\mathrm{V}$ ) reproduced at $37.5 \%$ and $20 \%$ respectively. No any newborn youngs from the ten pairs in line $A$. a. coreae 우 $\times A$. a. chejuensis $\delta$ (type VI) were obtained. The twenty three pairs of $A$. a. coreae 우 $\times A$. a. chejuensis $\delta^{7}$ (type VII) and ten pairs of $A$. a. coreae 우 $\times A$. a. coreae $\delta$ (type VIII) reproduced at $82.6 \%$ and $72.7 \%$ respectively.

Mean litter sizes were $4.77 \pm 1.02,5.14 \pm 2.41,4.80 \pm 0.44,4.80 \pm 1.30,4.60 \pm 1.29$, $4.73 \pm 0.92$ and $4.72 \pm 0.73$ (range, 2-9), for type I, type II, type IV, type V, type VII, type VIII and in total, respectively. The significant difference among them was not detected $(\mathrm{P}>0.05)$.

The mean body weights at birth were $2.42 \mathrm{~g} \pm 0.04(\mathrm{~N}=36), 2.39 \mathrm{~g} \pm 0.04(\mathrm{~N}=36)$, $2.41 \mathrm{~g} \pm 0.05(\mathrm{~N}=5), 2.42 \mathrm{~g} \pm 0.05(\mathrm{~N}=24), 2.41 \mathrm{~g} \pm 0.03(\mathrm{~N}=17), 2.53 \pm 0.12(\mathrm{~N}=59)$ and $2.31 \mathrm{~g} \pm 0.09(\mathrm{~N}=59)$ for type I, type II, type III, type IV, type V, type VII and type VIII, respectively.

\section{Histological examination}

The reproductive organs of $\mathrm{F} 1$ generation borne by $A$. a. chejuersis 우 $\times$ A. a. coreae $\delta$ wcre examined histologically. In each fomale, the primary and secondary follicle cells and Graafian follicles were observed (Fig. 1). On the other hand, concerning the males, the following abnormalities were detected: One had abnormal testes and cauda

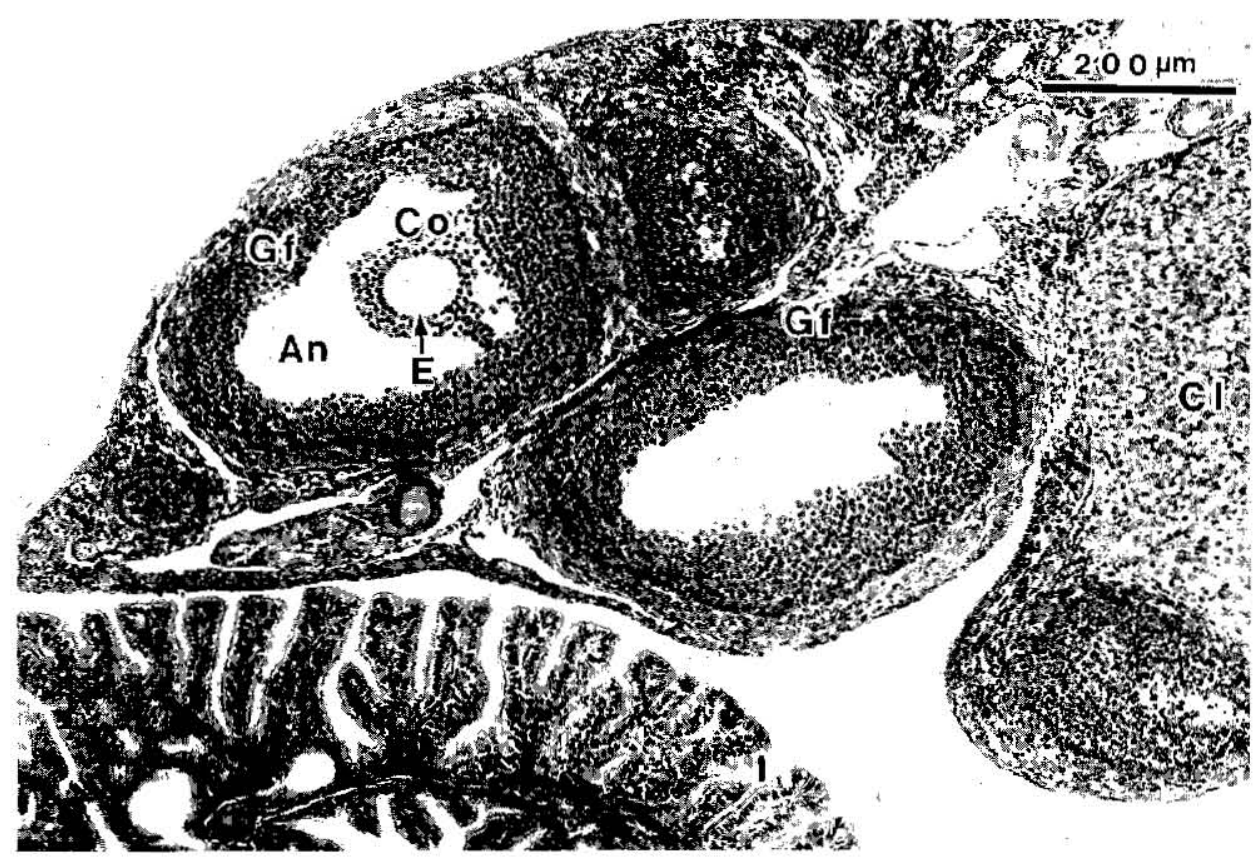

Fig. 1. Photograph of the ovary in $\mathrm{F} 1$ hybrids from $A$. a. chejuensis $(\stackrel{\circ}{\circ}) \times A$. a. coreae $\left(\delta^{\prime}\right)$ : Normal oogencsis in the ovary. An, antrum; Cl, corpus liteum; Co, cumulus oyphorus; E, egg; Gf, Graafian follicle; I, infundibulum. 


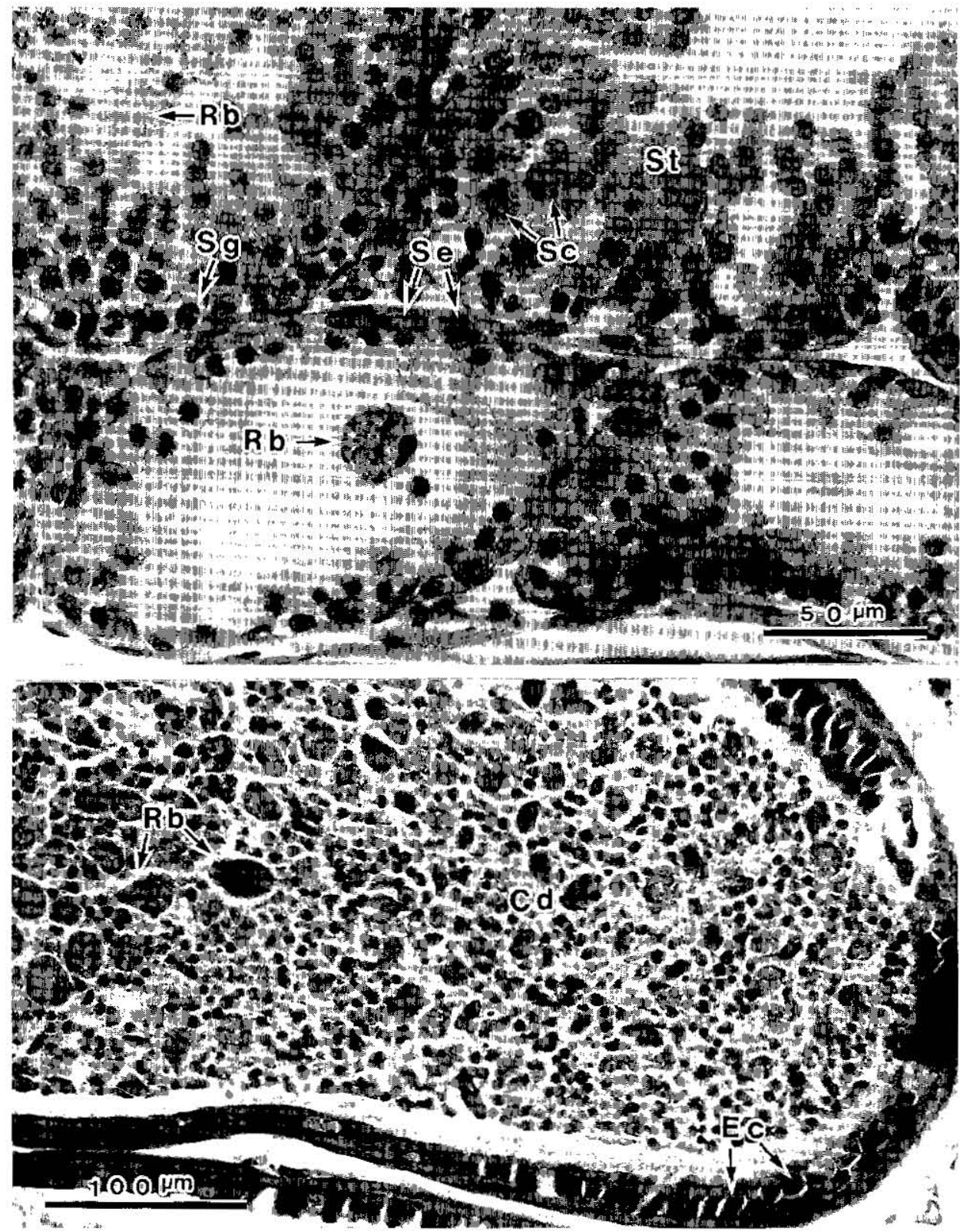

Fig. 2. Photographs of the testis and caudal epididymis in $\mathrm{F} 1$ hybrids from $A$, a. chejuensis ( 9 ) $\times \Lambda$. a. coreae $(\vec{s})$, a) The semiriferous tubules with Sertoli cell (Sc), spermatogonia (Sg), spermatocytes (Sc) and spermatids (St). b) The cauda epididymal tubules without sperm. $\mathrm{Cd}$, cell debris; Ec, epithelial cell; Rb, round body. 
Table 2. Spermatogenesis in F1 of Apodemus agrarius chejuensis (ㅇ) $\times$ A. a coreae $\left(\sigma^{7}\right)$.

\begin{tabular}{cccc}
\hline $\begin{array}{c}\text { Individual } \\
\text { Number }\end{array}$ & $\begin{array}{c}\text { Testes length } \\
(\mathrm{mm})\end{array}$ & $\begin{array}{c}\text { Spermatozoa } \\
\text { in testes }\end{array}$ & $\begin{array}{c}\text { Spcrmatozoa in } \\
\text { caudd epididymides }\end{array}$ \\
\hline 20 & absence & - & - \\
43 & 18.59 & - & - \\
60 & 18.91 & + & - \\
61 & 15.11 & + & - \\
65 & 17.41 & + & - \\
241 & 18.41 & + & - \\
245 & 19.14 & - & + \\
247 & 19.72 & ++ & + \\
249 & 18.73 & ++ & +++ \\
\hline Control & 19.76 & +++ & + \\
\hline
\end{tabular}

Testes length: length of major axis of right testis.

Spermatozoa in tesles and caudal cpididymides; , absence; + , rare; ++ , medium; +++ , many. Control datia was obtained from sexually active malcs ( 90 days old) of $A$. a. coreae.

epididymides; in another one, spermatogenesis did not occur and no sperm was observed in its caudal epididymis, although the testes developed (Fig. 2); in another five males, the testes developed and a few sperm were recorded in testes but no sperm existed in the caudal epididymis; and in another two males, the testes developed, spermatogenesis occurred and sperm existed in the caudal epididymis as seen in normal males. All the histological results indicates that in F1 males the spermatogenesis is not completed and, thus, they have some problems in the reproductive organs (Table 2).

\section{DISCUSSION}

\section{1) Reproductive compatibility between $A$. a. chejuensis and A. a. coreae}

It is difficult to know if morphologically different and geographically isolated populations of animals descrve subspecific or specific rankings, since the crucial test of interbreeding (Mayr, 1963) is not performed in nature. Breeding experiments can help to resolve the matter by revealing how much reproductive compatibility if any, exits. Extrapopulations are them made on the basis of its converse, reproductive isolation, making due allowance wherever possible for the lack of correspodence between nature and the experimental situation (Grant, 1974). The pairs of A. a. coreae 우 $\times$. a. chejuensis $\delta$ produced no newborn youngs. In addition, the three of five pairs of $A . a$. chejuensis + + $\times A$, a. coreae $\delta$ produced and reared successfully twenty-two newborn youngs in total. By contrast, the pairs composed of $\mathrm{F} 1$ generation of $A$. a. chejuevesis 우 $\times A$. a. coreae $\delta$ produced a few newborn youngs and no reproduction following post-parturition estrus occurred among them, even if the newborn youngs grew successfully. The results of these crossbreeding experiments suggested that a reproductive isolation would have existed between the striped field mouse population from the Korean mainland and the Chcju Island. In general, reproductive isolation is 
likely to contain the followings: firstly, (a) premating isolating mechanisms, which involving (i) seasonal and habitat isolation, (ii) reproductive isolation by behavioral discrepancy and (iii) physical disparity; and secondly, (b) postmating isolating mecharisms, which involving (i) isolation by failure in the fertilization, (ii) developmental disorder of fertilized eggs, (iii) hybrid inviability and (iv) hybrid inviability or sterility (Mayr, 1963; Futuyma, 1986). The species is a unit consisting of a large, intercommunicating genc pool, whereas the individuals is merely a temporary vessel holding a small portion of the contents of the gene pool for a short period of time(Mayr, 1963). Although crossbreeding experiments or artificial inseminations have been carried out with some mammals, there have been few fertilc hybrids because of the various postmating isolating mechanisms. As examples of hybrids which die during embryogenesis, the follows combinations have been well known: black rats Rattus rattus $\times$ brown rats Rattus nomegicus (Hiraiwa and Yoshida, 1955; Yoshida and Taya, 1977), goat Capra hircus $\times$ shecp Ovis aries (Alxander et al., 1967), rabbit Oryctolagus cuniculus $\times$ hares Lepus americamus (Chang et al., 1969) and ferrets Mustela furo $\times$ minks $M$. vison (Chang et al., 1969). By contrast, crosses between horses Equus caballus $\times$ donkeys $E$. asinus (Benirschke el al., 1962), horses Equus caballus $\times$ zebras E. grevyi (King et al., 1966), Syrian hamsters Mesocricetus neutoni $\times$ golden hamster $M$ auratus (Raicu and Bratoson, 1968) and Shaw's jirds Meriones shawii $\times$ Libyan jirds M. libycus (Lay and Nadler, 1969), all produce hybrids which survive to adulthood, although males and/or females are sterile.

\section{2) The taxonomic Position of the Korean striped field mouse from Cheju Island}

The failure in breeding in captivity does not mean directly the reproductive isolation in the wild (Rubinoff and Rubinoff, 1971). In genus Apodemus, this is more likely to occur because its breeding is not easy in captivity. Although it must be always kept in mind that fertility or sterility of hybrid is not the sole criterion defining species, the results of these crossbrceding experiments mean that an obvious reproductive isolation exists in the two subspecies, $A$ a. coreae and $A$. a. chejuensis. In other words, type VI pair seems to belong to (i) or (ii) of (b), and type I-V pairs are likely to belong to (iv) of (b). Fertile offspring are obtained from natural hybridization of wood mouse Peromyscus leucopuss with cotton mouse P. gossypinus (McCarley 1954, 1964), and from crossbreedings of coyotes Canis latrans with dogs C. farniliaris (Mengel, 1971), and Eurasian bank voles Clethrionomys glareolus with North American red-backed voles C. gapperi (Grant, 1974) under laboratory conditions: in such species, it is premating mechanisms that have the most important role in considering the taxonomic position.

Cheju Island was formed by series of volcanic activities at the end of Tertiary period in Cenozoic era and in recent it was 12,000 years since this island had been isolated from the Korean peninsula by the increase of sea level. Moreover, such island as Wan, Keoje, Jin and Chuja formed about 7,000 BP when sea level rose to its present depth (Ohshima, 1990).

As defined by Mayr (1969) a biological species comprises "groups of actually or potentially interbreeding populations which are reproductively isolated from other such groups". Jardin and Sibson (1971) stated that the distinct criteria for populations to be recognized as different species are: (a) dissimilarity in morphological attributes; (b) 
differences in ecological and/or geographical range; (c) degree of interferility; (d) cytological difference; and (e) differences of enzyme and proteins.

As mentioned above, the reproductive imcompatibility was confirmed between the local mouse populations from the Cheju Island and the Korean mainland, there is the gcographical isolation as premating mechanisms each other.

The results of the histological examination also suggest that a genetical variation would be existed, resulting in a speciation between the local populations from the Korean mainland and the Cheju Island. These lead to a conclusion that both populations of the striped field mouse from these two areas, which have been geographically separated from each other for a long lime, have reproductive isolations between thern. These data strongly support the specific division of "Apodemus chejuersis" vccuring in the Cheju Island from Apodemus agrarius in the mainland proposed by Koh and Yoo(1992). These results are consistent with recent new evidences on the taxonomy of the striped field mouse in Korea.

\section{REFERENCES}

Alexantar, G., D. William and L. Bailey 1967 Natural immunization in pregrant goats against red blood cells of their sheep $\times$ goat hybrid foctuses. Aust. J. Biol. Sci., 20: 1217-1226

Benirschke, T., L. E. Brownhill and M. M. Beath 1962 Somatic chromosomes of the horse, the donkey and their hybrids, the mule and the hiruy. J. Reprod. Fert., 4: 319-326

Chang, M. C., S. Pickworth and R. M. McGaughcy 1969 Experimental hybridization and chromosomes of hybrids. In "Comparative Mammalian Cytogenelics", ed. by K. Benirschke, Springer-Verliag, Berlin, pp. $132-145$

Corbet, G. B. 1978 The Mammals of the Palacarctic Region: a Taxonomic Review. British Museum (Natural History), Cornel] University Press, London artd Ithlaca, $314 \mathrm{pp}$.

Fituyma, D. J. 1986 Evolutionary Biology. 2nd ed. Sinauer Associates, Inc. Publishers, Sunderland, Massachusetts, $600 \mathrm{pp}$.

Grant, P. R. 1974 Reproductive compatibility of voles from separate continerts (Mammalia: Clethrionomys). J. Zool, Lond., 174: 245-254

Hiraiwa, Y. K. and H. Yoshida 1955 Conception by the cross between Rattus noregricus and $R$. rattus. 11. Breeding experiments by the artificial insemination. Sci. Bull. Fac., Kyzushu Lnit., 15: 267-273 (in Japanese with English summary)

Hong, H. K. and L. Y. Lee 1984 Studies on the biology of Apodemus agrarius in Korca. Thesis of Inchon Unit., 6: $417-439$

Jardin, N. and R. Sibson 1971 Mathematical taxonomy. John Wiley \& Sons Ltd., London

Jewell, P. A and P. J. Fullagar 1965) Fertility among range races of the field mouse (Apodemus sylvaticus) and their failure to form hybrids with the yclow-necked monse (Apodemus flaticollis). Evolution, 19: 175) - 181

Johnson, D. H. and J. K. Jones Jr. 1955 Three new rodents of the genera Micromys anil Apodtemus from Korea. Proc. Biol. Soc. Wash, 68: 167-172

Jones, J. K. Jr. and D. H. Johnson 1965 Synopsis of the lagomorphs and rodents of Korea. Univ. Kansas Publ. Mus. Nat. Hist, 16: $357-407$

King, J. M., R. V. Short, D. E. Mutton and J. L. Hamertom 1966 The reproductive physiology of male zcbra-horse and zebra-donky hybrids. In "Comparative Biology of Reproduction irl Mammals", ed. by I. W. Rowland, Academic Press, New York, pp. 511-527

Koh, H. S. 1986 Geographic variation of morphometric characters among three subspecies of striped field mice, Apodemus agrarius Pallas (Muridae, Rodentia), from Korea. Kor, J. Zool., 29: 272-282

Koh, H. S. 1987 Systematic studies of Korean rodents: III. Morphometric and chromosomal analyses of striped ficld mice, Apodemus agrarius chejuensis Jones and Johnson, from Jeju-Do. Kor. J. Syst. Zool., $3(1): 24-40$

Koh, H. S. 1991 Morphometric analyses with eight subspecies of striped field mice, Apodemus agrarius 
Pallas (Rodentia, Mammalia), in Asia: The taxonomic status of subspecies chejzensis at Cheju island, Korea. Kor, J. Syst. Zool., 7: 179-188

Koh, H. S. and B. S. Yoo 1992 Variation of milochondrial DNA in two subspecies of striped field mice, Apodemus agrarius coreae and Apodemus agrarius chejuensis, from Korea. Kor. d. Zool., 35: 332-338

Kuroda, N. 1934 Korean mamuals preserved in the collection of Marquis Yarmashina. J. Mamm., 15: 229-239

Lay, D. M. and C. F. Nadler 1969 Hybridization in the rodent genus Meriones: I. Breeding and cytological analyses of Meriones shawi ( 9 ) $\times$ Meriones libycus ( 3 ) hybrids. Cylogenetics, 8 : $35-50$

Mayr, E. 1963 Animal species and Evolution. Belknap Press of Harvard Lniv. Press, Cambridge, $797 \mathrm{pp}$.

McCarley, W. H. 1954 Natural hybridization in the Peromyscus leucoptes species group of mice. Evolution, 8: 314-323

McCarlcy, W. H. 1964 Ethological isolation in the cenospecies Peromyscus leucopus. Evolution, 18 331-332

Mengel, R. H. 1971 A study of dog-coyote hybrids and implications concerning hybridization in Canis J. Murnmal., 52: $316-336$

Musser, G. G. and M. D. Carleton 1993 Family Muridae. In "Mammal Species of The World", 2nd ed. by D. E. Wilson and D. M. Reeder, Smithsonian Institution Press, Washington \& London, pp. 501-755

Ohshima, K. 1990 The history of straits around the Japanese Islands in the Late-Quarternary. The Quartermary Research, 29: 193-208

Raicu, P. and S. Bratosin 1968 Interspecific reciprocal hybrids belween Mesocricetus auratus and $M$. nexitoni. Genet. Res., 11: 113-114

Rubinoff, R. W. and 1. Rubinoff 1971 Geographic and reproductive isolation in Atlantic and Pacific populations of Panamanian Bathygobius. Evolution, 25: 88-97

Thomas, O. 1907 The Duke of Bedford's zoological exploration in castem Asia. II. List of small mammals from Korea and Quclpart. Proc. Zool. Soc. London, 1906: 858-865

Tsuchiya, K. 1984 Notes on the development and utilization of characteristics in Apodemus spp. (A) Comprchensive study in the Ministry of Education; The development anci utilization of characteristic:s of nowly domesticated animals, $17-25$ (in Jajanese)

Tsuchiya, K. 1985 Notes on breeding of Apodemus spp. for laboratory animals. Bulletin of Kyushu Branch, Japan Experimental Animal Technician Associalion, 8: 4-12 (in Japantese)

Won, P. H. 1961 Studies on the ecological observation of rodentia in Manchuria and Korea (Part I). 7ool. Inst., I,iberal Arts Coll., Dong Kook Liniv., Seoul, 1-92

Yoshida, T. H. and C. Taya 1977 Studies on interspecific hybridization in the rodents: 1. Artificial insemination between the Norway rat $\left(\frac{9}{)}\right)$ and black rat. $\left(\delta^{\lambda}\right)$ and the resulting karyotypes in the hybrid blastcysts. Jpn. J. Geruet., 52: $289-299$ 